DOI: http://dx.doi.org/10.33846/hn41105

http://heanoti.com/index.php/hn

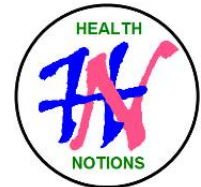

RESEARCH ARTICLE

URL of this article: http://heanoti.com/index.php/hn/article/view/hn41105

\title{
Application Of The WBZ (Warm Belt Zinger) Method To The Intensity Of Labor Pain At The BL 31-32 Meridian Points In PMB Semarang City
}

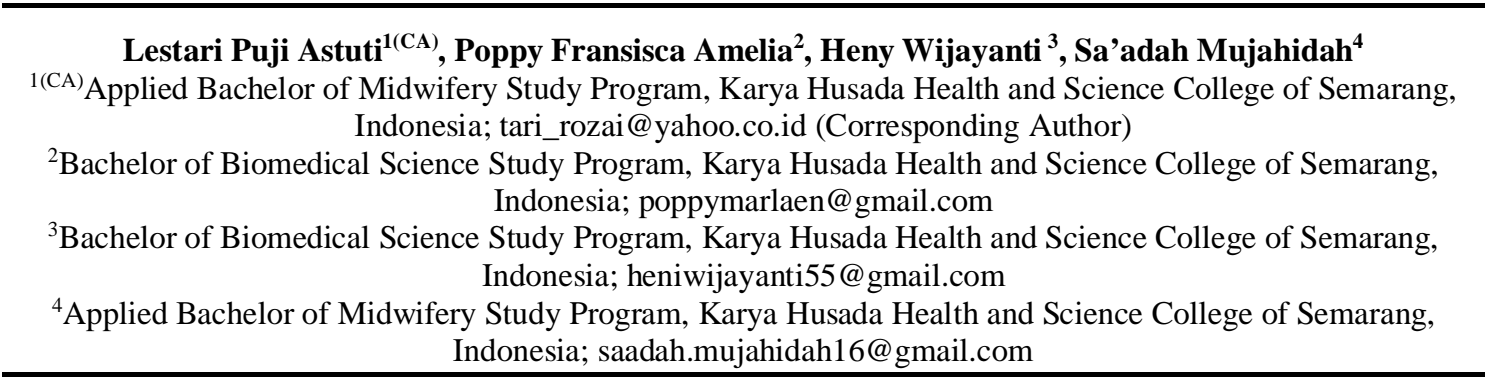

ABSTRACT

The research purposes to find out the effectiveness of WBZ (Warm Belt Zinger) and warm compresses at the meridian points BL 31 and 32 on the intensity of labor pain during. The pain that a woman experiences while entering labor is a physiological process. Labor pain is the most severe thing felt by women throughout their life. Non-pharmacological efforts are needed to reduce labor pain. Types of research was quasi-experiment with pretest-posttest with control design. The sampling technique used was accidental sampling with sample size of 30 people and divided into two groups intervention WBZ $\mathrm{n}=15$ and control (warm compress) $\mathrm{n}=15$. The subjects were the mothers who gave birth in were in the first phase of the active phase $(4-10 \mathrm{~cm}$ opening). There was differences in first time pain in the maternity before and after the WBZ group ( $\mathrm{p}$-value $=0.000$ ). There was a difference in first-time pain in the maternity before and after in the warm compress (p-value $=0.000)$. Statistical test results WBZ and warm compresses are effective for decrease the pain in first stage labor ( $\mathrm{p}$-value $=0.001$ ). WBZ and warm compresses effective to reduce labor pain in the first stage.

Keywords: ginger compress; warm compress; meridian points bl 31 and 32; intensity of labor pain

\section{INTRODUCTION}

Childbirth is the process of releasing the products of conception (fetus and placenta) that have been terminated or can live outside the womb through the birth canal or through other means, with assistance or without assistance (own strength). This process begins with true labor contractions, which are characterized by progressive changes in the cervix and ends with the delivery of the placenta. ${ }^{(1)}$

Maternal labor experiences pain during childbirth, but the intensity of pain experienced by each mother is different. Labor pain is one of the problems in labor that mothers usually feel, labor pain is a feeling of discomfort or discomfort due to stimulation of special nerve endings. During labor and vaginal delivery, pain is caused by uterine contractions, cervical dilation, and perineal distension. Visceral afferent nerve fibers that carry sensory impulses from the uterus enter the spinal cord in the tenth, eleventh, and twelfth thoracic segments and the first $\left(\mathrm{T} 10\right.$ to L1) ${ }^{(2)}$.

The pain that a woman experiences when she enters labor is a physiological or normal process ${ }^{(3,4)}$. Labor pain is a complex and unique phenomenon ${ }^{(4-9)}$. Labor pain is varied, subjective, and multidimensional ${ }^{(5,7,10)}$. This does not only involve the sensory component, but also involves emotional support, and knowledge levels are also very influencing ${ }^{(4,11)}$. Experience related to labor pain is the worst felt by women throughout their life ${ }^{(12)}$.

Efforts to reduce labor pain can be done both pharmacologically and nonpharmacological. Pharmacological pain management is more effective than non-pharmacological methods, but pharmacological methods are more expensive and have the potential to have adverse side effects. Meanwhile, non-pharmacological methods are cheaper, simpler, effective, and without any adverse effects ${ }^{(13)}$. Non-pharmacological management is very important because it does not harm the mother or fetus, does not delay labor if strong pain control is given, and does not have allergic effects to drug effects. Some techniques that can be used to reduce labor pain include 
breathing, massage, acupressure, double hips squee, warm showering or baths, warm compresses, counterpressure, slow dancing, or slow dancing ${ }^{(14)}$.

Compress is a technique that can be applied to reduce pain, be it cold compresses and warm compresses. The application of warm compresses that have been frequently done can collaborate with several herbal plants, one of which is ginger. Ginger (Zingiber officinale Rosc) is a rhizome plant that is very popular as a spice and medicinal ingredient. Several compounds, including gingerol, shogaol, and zingerone provide effects such as antioxidants, anti-inflammatory, and analgesic. Ginger compress is an action to provide warmth to certain areas using ginger decoction containing zingiberol and curcuminoids which reduce pain. The benefits of ginger compresses are to reduce pain due to warm ginger. The warm nature increases blood flow for analgesic effect and relaxes muscles so that the inflammatory process is reduced ${ }^{(15)}$.

Heat therapy in labor is usually performed on the back, lower abdomen, groin, and perineum ${ }^{(16)}$. When heat therapy is applied, the touch and temperature receptors are stimulated to create a pleasant sensation. Signals from pain will compete with these pleasant sensations to access the spinal cord, resulting in less pain sensation ${ }^{(17)}$.

Acupressure is the development of massage therapy that goes hand in hand with the development of acupuncture because acupressure massage techniques are a derivative of acupuncture. The technique in this therapy uses the fingers instead of needles but is done at the same points as those used in acupuncture therapy ${ }^{(18)}$. Acupressure points can respond to various types of stimulation. These stimuli can be in the form of mechanical, thermal, electric, magnetic stimuli or a combination of the four stimuli ${ }^{(18)}$. Some of the meridian points that can reduce pain are BL 31 and 32, acupressure at this point can reduce labor pain with gentle pressure ${ }^{(14)}$.

Research with 64 respondents was divided into 32 treatment groups and 32 control groups. The method used is a warm and cold pack that is placed on the back and lower abdomen during the first stage of labor and in the perineum during the second stage of labor using the intermittent technique. The difference in pain level was statistically significant between the two groups at the end of the acceleration phase with a P-value of 0.002 and a P-value of 0.000 at the second stage. Intermittent local hot and cold therapy is a safe and effective nonpharmacological method of relieving labor pain ${ }^{(19)}$.

Previous research on heat therapy used hot jars, warm compresses using a towel/cloth media. This technique is less effective because the temperature used is less stable, it is necessary to replace hot water repeatedly during heat therapy and the area for heat therapy tends to be wet, reducing the patient's comfort level. The physiological effects of heat therapy include reducing pain and increasing blood flow. , metabolism and elasticity of connective tissue ${ }^{(20)}$.

Heat therapy is more effective than non-steroidal anti-inflammatory drugs. With increasing temperature, tissues also become more flexible and blood vessels vasodilate. Heat allows an increase in tissue length when prolonged stretching is applied either during or immediately after heat therapy ${ }^{(21)}$.

Based on this description, this study will propose the use of WBZ (Warm Belt Zinger) warm compresses with ginger at the BL 31-32 meridian points to reduce pain during Phase I labor, which has the advantage of providing analgesic effects and muscle relaxation so that pain is reduced.

\section{METHODS}

This study used a quasi-experimental research design (pretest-posttest with control group design) to determine the effect of WBZ (Warm Belt Zinger) on decreasing the intensity of active phase I labor pain. Pretestposttest control group design scheme. The research instrument used was NRS (Numbering Rating Scale) so that the reliability test was not carried out because it was declared valid and reliable in the world. This research was conducted in PMB Semarang City. The research subjects were mothers who gave birth in PMB in the city of Semarang who were in the first phase of the active phase (4-10 cm opening).WBZ (Warm Belt Zinger) is a warm belt containing warm ginger to meet the need for comfort or relieve pain in certain areas. . The ginger used is dry red ginger as much as 100 grams then steamed to a temperature of $400 \mathrm{C}$, then put into the warm belt, the warm belt is attached to the Blended 31 and 32 meridian points for 15 minutes, during the contraction.

The sampling technique in this study was a non-probability sampling type of accidental sampling, with a total response rate of 30 people who met the inclusion and exclusion criteria. Measuring instruments in this study used observation sheets and partographs to monitor the progress of labor, a stopwatch, and a thermometer.

\section{RESULTS}

The characteristic of respondents can be seen in the table 1 , the majority of respondents have an age range of 20-35 years as many as 25 people $(83.33 \%), 17$ people $(56.67 \%)$ of high school education, and 17 primiparous parity $(56.67 \%)$.

Effectiveness of the application of WBZ (Warm Belt Zinger) and Warm Water Compress on the Decrease in First Stage Labor Pain Before and After Treatment can be seen at table 2. Table 2 The measurement results of the NRS scale (numeric rating scale) of the level of labor pain in the WBZ (Warm Belt Zinger) treatment group had an average pain reduction before and after treatment of 3.00 and a P-value of 0.000 , while the warm water compress group had an average reduction in pain before and after the treatment is 1.80 and the P-Value is 0.000 . 
From the statistical test, it was found that the application of WBZ (Warm Belt Zinger) and Warm Water Compress to reduce labor pain on the NRS measurement scale (numeric rating scale) had a p-value $<0.05$, which means that there was a significant difference between before and after the intervention in the WBZ group. (Warm Belt Zinger) and Warm Water Compress control.

Tabel 1 Characteristics of respondent

\begin{tabular}{|c|c|c|}
\hline Characteristics & Frequency & Percentage \\
\hline \multicolumn{3}{|l|}{ Age } \\
\hline Age $20-35$ & 25 & 83.33 \\
\hline Age $>35$ & 5 & 16.67 \\
\hline \multicolumn{3}{|l|}{ Education } \\
\hline Junior high & 7 & 23.33 \\
\hline Senior high & 17 & 56.67 \\
\hline Diploma & 2 & 6.67 \\
\hline Bachelor & 3 & 10.0 \\
\hline Post graduated & 1 & 3.33 \\
\hline \multicolumn{3}{|l|}{ Parity } \\
\hline Primipara & 17 & 56.67 \\
\hline Multipara & 8 & 26.66 \\
\hline Grande multipara & 5 & 16.67 \\
\hline
\end{tabular}

Tabel 2. Effectiveness of the application of WBZ (warm belt zinger) and warm water compress on the decrease in first stage labor pain before and after treatment

\begin{tabular}{lcccc}
\hline \multirow{2}{*}{ Labor pain (NRS) } & Pre & Post & \multirow{2}{*}{ Mean rank } & p-value \\
\cline { 2 - 3 } & Mean \pm SD & Mean \pm SD & & \\
\hline WBZ (warm belt zinger) & $8.40 \pm 0.828$ & $5.40 \pm 1.454$ & 8.00 & $0.000^{1}$ \\
Warm water compress & $7.93 \pm 0.799$ & $6.13 \pm 0.915$ & 8.00 & $0.000^{1}$ \\
\hline
\end{tabular}

${ }^{1}$ Wilcoxon

The Effectiveness of Reducing Stage I Labor Pain in the Application of WBZ (Warm Belt Zinger) Compared to Warm Water Compresses can be seen at table 3. The average pain difference in the WBZ (Warm Belt Zinger) group was 20.63 while the warm water compress group was 10.37 , it can be said that the application of WBZ (Warm Belt Zinger) was more effective in reducing the first stage labor pain compared to the application of Warm Water Compress seen from a p-value of $0.001(\mathrm{p}<0.05)$ which means there is a difference in pain difference in the WBZ (Warm Belt Zinger) group and the Warm Water Compress group.

Table 3. The effectiveness of reducing stage I labor pain in the application of WBZ (warm belt zinger) compared to warm water compresses

\begin{tabular}{cccc}
\hline Labor pain (NRS) & Mean \pm SD & Mean rank & p-value \\
\hline WBZ (warm belt zinger) & $1.50 \pm 0.509$ & 20.63 & \multirow{2}{*}{$0.001^{2}$} \\
Warm water compress & $2.40 \pm 1.163$ & 10.37 & \\
\hline
\end{tabular}

$$
{ }^{2} \text { Mann-Whitney }
$$

\section{DISCUSSION}

Labor pain that is felt by the mother occurs due to the transmission of pain impulses through certain nerves. In the first stage of labor, pain nerve impulses originating from the cervix and the corpus uteri. ${ }^{(22)}$ Pain impulses originating from the cervix and uterine body are transmitted by afferent nerve fibers through the uterine plexus, pelvic plexus, inferior, middle, posterior hypogastric plexuses and enter the lumbar which then enter the spinal via L1, T12, T11, T10. ${ }^{(23)}$ Pain that is felt in the lower abdomen and waist that occurs during the first stage of labor. The source of pain at the end of stage I and stage II comes from the lower genital tract, including the perineum, anus, vulva, and clitoris. Pain impulses are transmitted via the pudendal nerves to s4, s3, and s2. Pain is felt especially in the vulva and surrounding areas and the waist area ${ }^{(24)}$. Labor pain can be stressful causing excessive release of hormones such as catecholamines and steroids. This hormone can cause smooth muscle tension and vasoconstriction of blood vessels which can result in decreased uterine contractions, decreased uteroplacental circulation, reduced blood and oxygen flow to the uterus, and caused uterine ischemia which causes more painful implants ${ }^{(25)}$. Labor pain can affect functional mechanisms that cause a physiological stress response, there is the release of catecholamines and steroid hormones that stimulate smooth muscle tension and vasecontraction of blood vessels resulting in decreased uterine contractions. ${ }^{(26)}$. 
Feelings of anxiety and fear during labor can trigger the sympathetic and parasympathetic nervous systems, which can further increase the intensity of the pain you feel. The physical condition of the mother also greatly influences the intensity of pain during childbirth, the labor process requires considerable strength or energy, because if the mother experiences fatigue in labor, she will not be tolerant enough in dealing with the pain that arises so that the intensity of the pain that is felt is getting higher ${ }^{(27)}$.

The pain felt by the mother was getting stronger with increasing cervical dilation and the peak of pain occurred in the active phase until the cervix was dilated to reach $10 \mathrm{~cm}$. The pain and pain of childbirth are considered the most unpleasant and frightening things for the mother to give birth. Severe pain during childbirth must be managed effectively, if not resolved it can affect the condition of the mother and the fetus. There is nonpharmacological pain management that can be done to reduce labor pain ${ }^{(28)}$.

Compresses on the BL 31-32 meridian points can close the gate of pain messages that will be delivered to the spinal cord and brain, besides that with strong pressure when giving this technique it will be able to activate endorphins compounds that are in the synapse of the spinal cord cells and brain so that the transmission of pain messages can be inhibited causing a decrease in pain sensation ${ }^{(29)}$.

The measurement results of the NRS scale (numeric rating scale) in table 2 shows that the level of labor pain in the WBZ (Warm Belt Zinger) treatment group has an average pain reduction before and after treatment of 3.00 and a P-value of 0.000 , this indicates that WBZ is effective to reduce labor pain stage I.

The application of WBZ (Warm Belt Zinger) and warm water compresses are some of the labor pain management options that can improve the progress of labor. Ginger compress for childbirth can inhibit the secretion of the hormone prostaglandin because ginger has spicy and aromatic properties of oleoresins such as zingerone, gingerol, and shagaol contained in ginger can be useful for reducing pain ${ }^{(30)}$.

The application of warm compresses can collaborate with several herbal plants, one of which is ginger. Ginger (Zingiber officinale Rosc) is a rhizome plant that is very popular as a medicinal ingredient. The compounds contained in ginger provide antioxidant, anti-inflammatory, and analgesic effects. The benefits of ginger compresses are to reduce pain due to warm ginger. The warm nature increases blood flow for analgesic effect and relaxes muscles so that the inflammatory process is reduced ${ }^{(15,30)}$.

The measurement results of the NRS scale (numeric rating scale) in table 2 show that the level of labor pain in the Warm Water Compress treatment group has an average pain reduction before and after treatment is 1.80 and a P-value of 0.000 , this shows that warm water compresses are effective for reducing pain. 1st stage of labor.

Giving warm compresses during labor can widen the blood tissue so that it can increase blood flow to the pain area felt during labor, stop muscle disorders, reduce pain due to spasms or stiffness ${ }^{(30)}$.

The heat transmitted through the compress can relieve pain by eliminating inflammatory products, such as bradykinin, histamine, and prostaglandins that will cause local pain. Heat also stimulates nerve fibers that close the gates so that transmission of pain implants to the spinal cord and brain can be inhibited ${ }^{(31)}$. A warm compress can be used to relieve labor pain ${ }^{(30,32)}$.

Table 3 shows that the mean difference in pain in the WBZ (Warm Belt Zinger) group was 20.63 while the warm water compress group was 10.37. p-value $0.001<0.05$ this shows that WBZ (Warm Belt Zinger) is more effective in reducing the pain of first stage labor compared to warm compresses.

WBZ (warm belt zinger) is more effective to reduce the intensity of labor pain during the active phase of labor. This is because ginger compresses have spicy, warm, and aromatic properties contained in ginger which can be useful for reducing pain, this ginger compress is done for 15 minutes every time there is a contraction ${ }^{(33 \text {, }}$ 34).

WBZ (warm belt zinger) can have a gate control effect from the sensation of temperature inhibiting the sensation of pain in the brain, causing a sense of comfort causing endorphin secretion to inhibit enkephalin secretion, and the warm effect causing vasodilation of blood vessels thereby softening the thickened scar tissue which will reduce pressure at the end of the pain receptor ${ }^{(32)}$.

Pain is a physiological thing that will be experienced by a woman. However, the nature of labor pain is very subjective because the feeling of pain varies from person to person in terms of scale or level. The pain experienced by the mother in labor will increase with the frequency of contractions. However, this pain should not be left alone, so interventions need to be given to deal with the pain, one of which is using a warm belt zinger. WBZ (Warm Belt zinger) is believed to reduce pain because it can improve blood circulation so that it can provide comfort to the mother ${ }^{(35)}$

In the results of this study, there are differences in the effectiveness of using a warm belt zinger (WBZ) and a warm compress. This is because the warm belt zinger uses ginger which contains analgetic ingredients that inhibit prostaglandin synthesis in the body. In addition to producing a spicy and warm taste which can lead to vasodilation of blood vessels, causing a feeling of comfort and pain will be reduced. Besides that, the aromatherapy effect of ginger also relaxes the mind so that respondents do not focus too much on the pain they are experiencing $(15,34,36)$. Ginger has the spicy, bitter, and aromatic properties of oleoresins such as zingerone, gingerol, and shogaol. Oleoresin has strong anti-inflammatory and antioxidant potential. The non-volatile water 
and oil content in ginger acts as an enhancer that can increase the permeability of oleoresin to penetrate the skin without causing irritation or damage to the peripheral circulation. ginger contains operation or gingerol which can inhibit prostaglandin synthesis so that pain relief or inflammation is reduced ${ }^{(33)}$.

\section{CONCLUSION}

WBZ (Warm Belt Zinger) can be used as an alternative to non-pharmacological pain management in stage I labor which is safe, inexpensive, and effective and with ginger-based ingredients that are easily available. There is a difference in the effectiveness of ginger compresses and warm compresses on the intensity of labor pain during the 1st stage. It is hoped that midwives and health workers can apply WBZ (Warm Belt Zinger) as a nonpharmacological therapy to treat labor pain in the first stage.

\section{REFERENCES}

1. Sulistyawati A, Nugraheny E. Asuhan Kebidanan pada Ibu Bersalin. Jakarta: Salemba Medika; 2012.

2. Oktarina M. Buku Ajaran Asuhan Kebidanan Persalinan dan Bayi Baru Lahir. Yogyakarta: DEEPUBLISH; 2016.

3. Jones LE, Whitburn LY, Davey M-A, Small R. Assessment of pain associated with childbirth: Women' s perspectives, preferences and solutions. Midwifery. 2015;31(7):708-12.

4. Whitburn LY, Jones LE, Davey M-A, Small R. Women's experiences of labour pain and the role of the mind: an exploratory study. Midwifery. 2014;30(9):1029-35.

5. Bergh I, Söderlund T, Vinterskog L, Mårtensson LB. Reliability and validity of the Acceptance Symptom Assessment Scale in assessing labour pain. Midwifery. 2012;28(5):e684-e8.

6. Burkle CM, Olsen DA, Sviggum HP, Jacob AK. Parturient recall of neuraxial analgesia risks: Impact of labor pain vs no labor pain. Journal of Clinical Anesthesia. 2017;36:158-63.

7. Hensley JG, Collins MR, Leezer CL. Pain management in obstetrics. Critical Care Nursing Clinics. 2017;29(4):471-85.

8. Jahdi F, Sheikhan F, Haghani H, Sharifi B, Ghaseminejad A, Khodarahmian M, et al. Yoga during pregnancy: The effects on labor pain and delivery outcomes (A randomized controlled trial). Complementary therapies in clinical practice. 2017;27:1-4.

9. Taavoni S, Sheikhan F, Abdolahian S, Ghavi F. Birth ball or heat therapy? A randomized controlled trial to compare the effectiveness of birth ball usage with sacrum-perineal heat therapy in labor pain management. Complementary therapies in clinical practice. 2016;24:99-102.

10. Carvalho B, Zheng M, Aiono-Le Tagaloa L. Evaluation of experimental pain tests to predict labour pain and epidural analgesic consumption. British journal of anaesthesia. 2013;110(4):600-6.

11. Ellison DL. Physiology of pain. Critical Care Nursing Clinics. 2017;29(4):397-406.

12. Ozgoli G, Mobarakabadi SS, Heshmat R, Majd HA, Sheikhan Z. Effect of LI4 and BL32 acupressure on labor pain and delivery outcome in the first stage of labor in primiparous women: A randomized controlled trial. Complementary therapies in medicine. 2016;29:175-80.

13. Budiarti KD. Hubungan akupresur dengan tingkat nyeri dan lama persalinan kala I pada ibu primipara di Garut. Universitas Indonesia. 2011.

14. Studebaker SS. The Birth Partner: A Complete Guide to Childbirth for Dads, Doulas, and All Other Labor Companions. Journal of Midwifery \& Women's Health. 2009;54(6):e71-e.

15. Prihandhani IS. Pengaruh Pemberian Kompres Hangat Rebusan Parutan Jahe Terhadap Nyeri Pada Lansia Dengan Osteoartritis Di Pejeng Kangin Kabupaten Gianyar. Jurnal Dunia Kesehatan. 2016;5(2).

16. Simkin P. Just another day in a woman's life? Part 11: Nature and consistency of women's long-term memories of their first birth experiences. Birth. 1992;19(2):64-81.

17. Macintyre PE, Schug S, Scott D, Visser EJ, Walker SM. Acute pain management: scientific evidence: Australian and New Zealand College of Anaesthetists; 2010.

18. Lathifah NS, Iqmy LO. Pengaruh L14 terhadap Peningkatan Kontraksi pada Kala I Persalinan. Jurnal Kesehatan. 2018;9(3):433-8.

19. Ganji Z, Shirvani MA, Rezaei-Abhari F, Danesh M. The effect of intermittent local heat and cold on labor pain and child birth outcome. Iranian journal of nursing and midwifery research. 2013;18(4):298.

20. Malanga GA, Yan N, Stark J. Mechanisms and efficacy of heat and cold therapies for musculoskeletal injury. Postgraduate Medicine. 2015;127(1):57-65.

21. Corti L. Nonpharmaceutical approaches to pain management. Topics in companion animal medicine. 2014;29(1):24-8.

22. Emelonye AU, Vehviläinen-Julkunen K, Pitkäaho T, Aregbesola A. Midwives perceptions of partner presence in childbirth pain alleviation in Nigeria hospitals. Midwifery. 2017;48:39-45.

23. Rejeki S, editor Counter-Pressure Practice Method by Spuses for Reducing Pain of Mothers In First Stage Labour. 2nd International Seminar on Education Technology 2016; 2016: State University of Semarang.

24. Bobak L. Buku ajar keperawatan maternitas. 4, editor. Jakarta: EGC; 2004. 
25. Wulandari DA, Putri VTA. Aplikasi Tekhnik Effleurage sebagai Penatalaksanaan Nyeri Persalinan Ibu Bersalin di Bidan Praktik Mandiri Kecamatan Tembalang. Proceeding of The URECOL. 2018:538-43.

26. Rejeki S, editor Tingkat Nyeri Persalinan Melalui Acupressure Metakarpal Ibu Dalam Prosses Persalinan Kala I. Prosiding Seminar Nasional \& Internasional; 2015.

27. Jones L, Othman M, Dowswell T, Alfirevic Z, Gates S, Newburn M, et al. Pain management for women in labour: an overview of systematic reviews. Cochrane database of systematic reviews. 2012(3).

28. Karsten P KA, Tennant A. J Rehabil Med. The Use of The Visual Analogue Scale (VAS) in Rehabilitation Outcomes. 2012.

29. Ayu PD. Efektivitas Masase Counter Pressure Terhadap Penurunan Tingkat Nyeri Persalinan Kala 1 Fase Aktif Pada Ibu Multipara Di Rsud Kota Semarang: Fakultas Ilmu Keperawatan UNISSULA; 2015.

30. Masyhurrosyidi H, Kumboyono K, Utami YW. Pengaruh Kompres Hangat Rebusan Jahe Terhadap Tingkat Nyeri Subakut dan Kronis pada Lanjut Usia dengan Osteoarthtritis Lutut di Puskesmas Arjuna Kecamatan Klojen Malang Jawa Timur. Majalah Kesehatan FKUB. 2016;1(1):39-44.

31. Juliani ES, Susan Y. Kompres Hangat Mempengaruhi Tingkat Nyeri Persalinan. Jurnal Bidang Ilmu Kesehatan. 2016;6(2):11.

32. Samsudin AR, Kundre R, Onibala F. Pengaruh Pemberian Kompres Hangat Memakai Parutan Jahe Merah (Zingiber Officinale Roscoe Var Rubrum) Terhadap Penurunan Skala Nyeri PadaPenderitaGout Artritis Di Desa Tateli Dua Kecamatan Mandolang Kabupeten Minahasa. Jurnal Keperawatan. 2016;4(1).

33. Anisa IN. Efektifitas Kompres Air Hangat Dan Kompres Jahe Terhadap Penurunan Nyeri Rematik Pada Lansia Di Desa Adiarsa Kecamatan Kertanegara: Universitas Muhammadiyah Purwokerto; 2015.

34. Zuriati Z. Efektifitas Kompres Air Hangat Dan Kompres Jahe Terhadap Penurunan Nyeri Pada Pasien Asam Urat Di Puskesmas Lubuk Begalung Tahun 2017. The Shine Cahaya Dunia S-1 Keperawatan. 2017;2(2).

35. Ropyanto CB, Sinaga HE. Pengaruh Kompres Hangat Terhadap Nyeri Sendi Pada Lansia (60-74 Tahun). 2015.

36. Rahayu HT, Sri N, Sunardi S, editors. The Effectiveness of Red Ginger Compress Therapy (Zingiber officinale rosc. var. rubrum) on Elders with Joint Pain. Health Science International Conference (HSIC 2017); 2017: Atlantis Press. 